\title{
ANALISA PROKSIMAT DAN ORGANOLEPTIK KERUPUK IKAN LELE (Clarias $s p$ ) TERHADAP STANDAR NASIONAL INDONESIA (SNI) DI KECAMATAN RIMBO BUJANG KABUPATEN TEBO PROVINSI JAMBI
}

\author{
Hari Cahyono ${ }^{1}$, Rini Hertati ${ }^{2}$, Djunaidi ${ }^{3}$ \\ 1 Mahasiswa Program Studi Pemanfaatan Sumberdaya Perikanan \\ 2 dan 3 Pengajar Pada Program Studi Pemanfaatan Sumberdaya Perikanan
}

\begin{abstract}
ABSTRAK
Kerupuk merupakan salah satu makanan ringan yang disukai oleh masyarakat, Sebagai sumber protein, padapengolahan kerupuk biasanya ditambahkan bahan daging ikan dan dikenal sebagai kerupuk ikan.

Tujuan penelitian ini adalah menentukan nilai proksimat dan nilai organoleptik kerupuk ikan lele (Clarias $s p$ ). Analisa proksimat dilakukan untuk mengetahui komponen utama dari suatu bahan. Untuk pengujian dalam penelitian ini terdiri dari kadar air, kadar abu tak larut dalam asam dan kadar protein. Sedangkan analisa organoleptik adalah pengujian yang didasarkan pada proses penginderaan manusia untuk menilai tingkatan mutu menggunakan lembar penilaian sensori berdasarkan kenampakan, bau, rasa (matang), tekstur dan jamur.

Metode penelitian yang digunakan adalah metode survei langsung ke lokasi pembuatan kerupuk ikan lele (Clarias sp), kemudian hasil analisa proksimat dan organoleptik disajikan dalam bentuk tabel dan diinterpretasikan dalam bentuk grafik.

Hasil uji proksimat yang dilakukan sebanyak dua kali yakni pengujian pertama (minggu pertama) dan pengujian kedua (minggu ketiga) menghasilkan nilai proksimat kerupuk ikan lele (Clarias $s p$ ) yang berbeda dan mengalami peningkatan. Pada pengujian minggu pertama memiliki nilai kadar air 7,2829\% kadar abu tak larut dalam asam 4,4383 \% dan kadar protein 3,0000 \%, sedangkan pada pengujian kedua memiliki nilai kadar air 8,6099 \% kadar abu tak larut dalam asam 4,9140\% dan kadar protein 3,8629\%.

Hasil akhir uji organoleptik kerupuk ikan lele (Clarias sp) dengan nilai kenampakan 6,0 bau 7,0 rasa (matang) 7,0 tekstur 7,0 dan jamur 9,0.
\end{abstract}

Kata kunci : Uji Proksimat, Uji Organoleptik, Kerupuk Ikan Lele (Clarias sp)

\section{PENDAHULUAN}

Kerupuk merupakan salah satu makanan ringan yang disukai oleh masyarakat, baik dikonsumsi sebagai lauk makan nasi ataupun dimakan sebagai makanan ringan. kerupuk yang beredar di pasaran pada umumnya kaya akan unsur karbohidrat, tetapi miskin akan unsur protein. sebagai sumber protein, padapengolahan kerupuk biasanya ditambahkan bahan daging ikan dan 
SEMAH : Journal Pengelolaan Sumberdaya Perairan

VOL. 2 No. 3

Desember 2018

dikenal sebagai kerupuk ikan (Adawyah, 2007).

Tujuan dari penelitian ini adalah :

1. Untuk mengetahui uji proksimat (kadar air, kadar abu tak larut dalam asam dan kadar protein) terhadap kerupuk ikan lele (Clarias sp) Kelompok Pembudidaya Ikan di (POKDAKAN) Kasih Ibu Kecamatan Rimbo Bujang Kabupaten Tebo terhadap Standar Nasional Indonesia (SNI)

2. Untuk mengetahui uji organoleptik (kenampakan, bau, rasa, tekstur dan jamur) terhadap kerupuk ikan lele (Clarias sp) di Kelompok Pembudidaya Ikan(POKDAKAN) Kasih Ibu Kecamatan Rimbo Bujang Kabupaten Tebo terhadap Standar Nasional Indonesia (SNI)

\section{METODOLOGI PENELITIAN}

Penelitian dilaksanakan pada tanggal 08 Agustus - 13 Oktober 2018 di Kelompok Pembudidaya Ikan (POKDAKAN) Kasih Ibu Kecamatan Rimbo Bujang Kabupaten Tebo Provinsi Jambi dan untuk Uji Laboratorium dilaksanakan di Universitas Andalas, Padang.

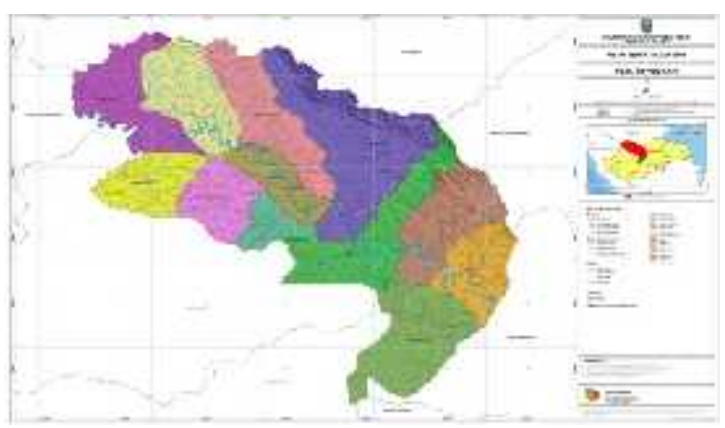

http://ojs.umb-bungo.ac.id/index.php/SEMAHJPSP ISSN : 2580-0736

Gambar 3.1. Peta Lokasi Penelitian

Bahan yang digunakan dalam penelitian uji proksimat dan uji organoleptik ini adalah kerupuk ikan lele (Clarias $s p$ ) yang berasal dari produksi kerupuk ikan lele (Clarias sp) di Kelompok Pembudidaya Ikan (POKDAKAN) Kasih Ibu Kecamatan Rimbo Bujang Kabupaten Tebo Provinsi Jambi, Sedangkan bahan kimia yang digunakan ialah Aquades, Asam Sulfat, Selenium Reagent Mixture, Sulfuric Acid, $\mathrm{NaOH} 50 \%$, Asam Borat, HCL, (campuran metil merah $0,2 \%$ ).

Adapun alat yang digunakan dalam penelitian ini ialah Cawan, Blender, Timbangan Analitik, Ove- Desikator, Penjepit, Labu Kjeldahl, G $\quad$ Jkur, Labu Ukur, Corong, Alat Pemanas, Erlenmeyer, Alat Destilasi Protein, Buret, Pipet Gondok, Bola Hisap, Alat Tanur, Waterbet, Kertas Saring, Botol Semprot, Batang Pengaduk, Kertas Saring, Toples, Thermometer, Timbangan Digital, Piring.

Pengambilan sampel dalam penelitian ini dengan metode Purposive Samplingyaitu, penentuan sampel dilakukan berdasarkan tujuan penelitian.

Proses Uji Proksimat

a) Analisis Kadar Air (SNI 2354.2-2015)

b) Analisis Kadar Abu Tak Larut Dalam Asam (SNI 2354.1-2010)

c) Analisis Kadar Protein (AOAC 1995)

Proses Uji Organoleptik 

a) Kenampakan
b) $\mathrm{Bau}$
c) Rasa (matang)
d) Tekstur
e) Jamur

\section{Analisis Data}

Analisis Data Uji Proksimat

Untuk perhitungan uji proksimat (kadar air, kadar abu tak larut dalam asam dan kadar protein) dihitung menggunakan rumus sebagai berikut :

a) Perhitungan Kadar Air (SNI 2354.22015)

$$
\% \text { Kadar air }=\frac{\mathrm{B}-\mathrm{C}}{\mathrm{B}-\mathrm{A}} \times 100 \%
$$

b) Perhitungan Kadar Abu Tak Larut Dalam Asam (SNI 2354.1-2010)

$\%$ Kadar abu tak larut asam = $\frac{\mathrm{C}-\mathrm{A}}{\text { Berat sampel (g) }} \times 100 \%$

c) Perhitungan Kadar Protein (AOAC 1995)

$$
\begin{aligned}
& \% \text { Nitrogen }= \\
& \frac{(\mathrm{ml} \mathrm{HCL}-\text { ml blanko }) \times N ~ H C l \times 14.007 \times \mathrm{fp}_{\mathrm{p}}}{\text { Berat sampel }(\mathrm{mg})} \\
& \% \text { Protein }=\% \mathrm{~N} \times \text { Faktor konversi } \\
& \text { Faktor Konversi : } 6,25
\end{aligned}
$$

\section{Analisis Data Uji Organoleptik}

Data yang diperoleh dari lembar penilaian skoring ditabulasi dan ditentukan nilai mutunya dengan mencari hasil rerata pada setiap parametersensori pada tingkat kepercayaan 95\%. Perhitungan hasil pengujian sensori dilakukan untuk setiap spesifikasi dalam lembar penilaian.

Untuk menghitung interval nilai mutu rerata dari setiap parameter sensori digunakan rumus sebagai berikut :

$$
\begin{aligned}
& m(x-(1.96 \cdot x / \sqrt{n})) \leq \mu \leq 1 x+(1.96 .8 / \sqrt{n})) \simeq 959 . \\
& \bar{x}=\frac{\sum_{n}^{n} x}{n} \\
& S^{2}=\frac{\sum_{f}^{n}\left(x_{r}-\bar{x}\right)^{\prime}}{n} \\
& x=\sqrt{\sum_{i=1}^{L}\left(x_{i}-\bar{x}\right)^{2}}
\end{aligned}
$$

\begin{tabular}{|c|c|c|c|c|}
\hline $\begin{array}{l}\mathrm{N} \\
\mathrm{o}\end{array}$ & $\begin{array}{l}\text { Paramete } \\
\mathrm{r}\end{array}$ & $\begin{array}{l}\text { Pengujia } \\
\mathrm{n} \mathrm{Ke} \mathrm{I} \\
\text { (Minggu } \\
\text { Pertama) } \\
\%\end{array}$ & $\begin{array}{l}\text { Pengujia } \\
\mathrm{n} \mathrm{Ke} \mathrm{II} \\
\text { (Minggu } \\
\text { Ketiga) } \\
\%\end{array}$ & $\begin{array}{l}\text { SNI } \\
(\%)\end{array}$ \\
\hline 1 & $\begin{array}{l}\text { Kadar } \\
\text { Air }\end{array}$ & 7,2829 & 8,6099 & $\begin{array}{l}\text { Mak } \\
\text { S } \\
12.0\end{array}$ \\
\hline 2 & $\begin{array}{l}\text { Kadar } \\
\text { Abu Tak } \\
\text { Larut } \\
\text { Dalam } \\
\text { Asam }\end{array}$ & 4,4383 & 4,9140 & $\begin{array}{l}\text { Mak } \\
\text { s } 0,2\end{array}$ \\
\hline 3 & $\begin{array}{l}\text { Kadar } \\
\text { Protein }\end{array}$ & 3,0000 & 3,8629 & $\begin{array}{l}\text { Min } \\
5\end{array}$ \\
\hline
\end{tabular}

\section{HASIL DAN PEMBAHASAN}

Analisa Proksimat

Hasil uji proksimat kerupuk ikan lele (Clarias $s p$ ) mentah dapat dilihat pada tabel 4.1 dibawah ini :

Tabel 4.1 Hasil Uji Proksimat Kerupuk Ikan Lele (Clarias sp) Mentah

Sumber : Data Laboratorium

\section{Kadar Air}

Kadar air dipengaruhi oleh suhu pengukusan adonan $\pm 52^{\circ} \mathrm{C}$, lama waktu pengukusan adonan selama \pm 25 menit, 
komposisi tepung tapioka $1 \mathrm{Kg}$ dan tepung terigu 200 gram yang dipergunakan, suhu penyimpanan $\pm 31^{\circ} \mathrm{C}$ serta ketebalan kerupuk. Tinggi rendahnya kadar air kerupuk menurut Salamah dkk.,(2008) dipengaruhi beberapa hal diantaranya kelembaban udara disekitar bahan,tingkat ketebalan kepingan kerupuk mentah serta tekstur bahan. Air akan mudah menguap pada produk yang tipis sehingga kadar airnya semakin kecil dan sebaliknya.

Lama waktu pengukusan adonan juga mempengaruhi kadar air, hal ini disebabkan selama proses pemanasan, adonan melepaskan kandungan air sehingga terjadi penurunan kadar air pada produk, selain proses pengukusan adonan, proses pengeringan juga menyebabkan penurunan kadar air.

\section{Kadar Abu Tak Larut Dalam Asam}

Tingginya kadar abu tidak larut asam ini juga didugadisebabkan oleh adanya kontaminasi pada saat pengeringan. Pengeringan dengansinar matahari sangat rentan terhadap cemaran debu dan pasir.Komponen abutidak larut asam ini dapat merusak kinerja organ ginjal jika dikonsumsi dalamjumlah yang besar (Nurjanah 2010).

\section{Kadar Protein}

Kadar protein kerupuk ikan lele (Clarias sp) mentah dipengaruhi oleh rendahnya komposisi ikan dalam proses pembuatan kerupuk dan suhu pengukusan adonan yang cukup tinggi yaitu $52^{\circ} \mathrm{C}$.

$$
\text { Panas merupakan metode }
$$
pengolahan yang paling destruktif, asamasamamino yang paling terpengaruh adalah lisin dan treonin.Faktor yang palingberpengaruh terhadap tingkat kerusakan pada prosesing panas adalah lama waktudan temperatur pemanasan (Apriyantono, 2002).Ditambahkan Huda dkk., (2010), bahwa kadar protein yang rendah menunjukkan kandungan sumber protein yang sedikit dalam formulasi yang digunakan dalam pembuatan kerupuk.

\section{Analisa Organoleptik}

Pengujian organoleptik adalahpengujian yang didasarkan pada prosespenginderaan.

Penginderaan diartikansebagai suatu proses fisiopsikologis,yaitu kesadaran atau pengenalan alatindera akan sifat-sifat benda karenaadanya rangsangan yang diterima alatindera yang berasal dari benda tersebut.Penginderaan dapat juga berarti reaksimental (sensation) jika alat inderamendapat rangsangan (stimulus).Reaksi atau kesan yang ditimbulkankarenaadanya rangsangan dapat berupasikap menyukai atau tidak menyukaiakan benda penyebab rangsangan (Romansyah, 2012).

Hasil akhir uji organoleptik kerupuk ikan lele (Clarias sp) dapat dilihat pada tabel 4.2 dibawah ini : 
SEMAH : Journal Pengelolaan Sumberdaya Perairan

VOL. 2 No. 3

Desember 2018

Tabel 4.2 Hasil Uji Organoleptik Kerupuk Ikan Lele (Clarias sp)

\begin{tabular}{|c|c|c|c|}
\hline No & Parameter & $\begin{array}{l}\text { Nilai } \\
\text { Akhir }\end{array}$ & SNI \\
\hline 1 & Kenampakan & 6,0 & $\begin{array}{l}\text { Min } \\
7,0\end{array}$ \\
\hline 2 & $\mathrm{Bau}$ & 7,0 & $\begin{array}{l}\text { Min } \\
7,0\end{array}$ \\
\hline 3 & $\begin{array}{l}\text { Rasa } \\
\text { (matang) }\end{array}$ & 7,0 & $\begin{array}{l}\text { Min } \\
7,0\end{array}$ \\
\hline 4 & Tekstur & 7,0 & $\begin{array}{l}\text { Min } \\
7,0\end{array}$ \\
\hline 5 & Jamur & 9,0 & $\begin{array}{l}\text { Min } \\
7,0\end{array}$ \\
\hline
\end{tabular}

Sumber : Hasil Pengolahan Data Oleh

Peneliti di Fakultas Perikanan UMB, 2018

\section{Kenampakan}

Rochima dkk., (2015) menyatakan bahwa kenampakanmerupakan parameter organoleptik yang cukup penting karena menentukan kesan pertama konsumen terhadap produk baik disukai maupun tidak disukai. Setelah itu, konsumen baru melihat atribut yang lain seperti aroma, tekstur, warnadan rasa.

Perhitungan nilai sensori kenampakan :

$\mathrm{P}(6,2$ - $(1,96.0,98 / 2,24)) \leq \leq(6,2+$ $(1,96$. 0,98/2,24))

$\mathrm{P}(6,2-0,44 \leq \leq 6,2+0,44)$

$\mathrm{P}(5,76 \leq \leq 6,64)$

$\mathrm{P}=5,76$ dibulatkan menjadi 6,0

Hal ini disebabkan pada proses pengukusan adonan dan pengeringan adonan,terjadi perubahan warna bahan yang disebabkan oleh adanya proses gelatinisasi. Semakin lama dan semakin tinggi suhu yang digunakan untuk proses gelatinisasi akan semakin melarutkan
http://ojs.umb-bungo.ac.id/index.php/SEMAHJPSP ISSN : 2580-0736

komponen kimia dalam sel sehingga memungkinkan gula dan protein untuk bereaksi menghasilkan pigmen berwarna cokelat (Hapsari, 2008).

\section{Bau}

Bau merupakan salah satu parameter yang menentukan rasa enak dari suatu makanan. Konsumen akan menerima produk pangan apabila memiliki aroma yang tidak menyimpang dari aroma normal (Purwanto dkk.,2013).

Perhitungan nilai sensori bau :

$\mathrm{P}(7,8-(1,96$. $0,98 / 2,24)) \leq \leq(7,8+$ $(1,96.0,98 / 2,24))$

$\mathrm{P}(7,8-0,44 \leq \leq 7,8+0,44)$

$\mathrm{P}(7,36 \leq \leq 8,24)$

$\mathrm{P}=7,36$ dibulatkan menjadi 7,0

Menurut Subagio (2006), pada proses pengukusan granula patiakan mengalami hidrolisis menghasilkan monosakarida sebagai bahan baku penghasil asam-asam organik, terutama asam laktat. Senyawa asam laktat akan bercampur dengan ikan, ketika dilakukan pengukusan akan menghasilkan aroma dan cita rasa khas yang dapat menutupi aroma dan cita rasa dari ikan.

\section{Rasa (matang)}

Rasa merupakan kualitas sensori suatu produk yang berkaitan dengan indera perasa dan menjadikan faktor penentu daya terima konsumen terhadap produk pangan (Afrianti dkk.,2013).

Perhitungan nilai sensori rasa (matang) : 
$\mathrm{P}(7-(1,96.0 / 2,24)) \leq \leq(7+(1,96.0 /$ $2,24))$

$\mathrm{P}(7-0 \leq \leq 7+0)$

$\mathrm{P}(7 \leq \leq 7)$

$\mathrm{P}=7$

Herliani (2008), bahwa rasa dapat dipengaruhi oleh pemanasan atau pengolahan yang dilakukan sehingga mengakibatkan kemunduran (degradasi) penyusun cita rasa.

\section{Tekstur}

Tekstur merupakan ciri suatu bahan sebagai akibat perpaduan dari beberapa sifat fisik yang meliputi ukuran, bentuk, jumlah dan unsur-unsur pembentukan bahan yang dapat dirasakan oleh indera peraba dan perasa, termasuk indera mulut dan penglihatan (Midayanto dan Yuwono, 2014).

Perhitungan nilai sensori tekstur :

$\mathrm{P}(7,8-(1,96.0,98 / 2,24)) \leq \leq(7,8+$ $(1,96$. 0,98 / 2,24))

$\mathrm{P}(7,8-0,44 \leq \leq 7,8+0,44)$

$\mathrm{P}(7,36 \leq \leq 8,24)$

$\mathrm{P}=7,36$ dibulatkan menjadi 7,0

Apriliani (2010), Keberadaan air dalam suatu produk akan mempengaruhi tekstur. Karena air yang terdapat didalamnya akan mempengaruhi keras atau lunaknya suatu produk.

\section{Jamur}

Pertumbuhan jamur di permukaan bahan makanan mudah dikenali karena seringkali membentuk koloni berserabut seperti kapas.Tubuh jamur berupa benang yang disebut hifa, sekumpulan hifa disebut miselium.Miselium dapat mengandung pigmen dengan warna-warna merah, ungu, kuning, coklat, abu-abu dan sebagainya. Jamur juga membentuk spora berwarna hijau, biru-hijau, kuning, jingga, merah muda dan sebagainya (Tournas, dkk., 2001).

Perhitungan nilai sensori jamur :

$\mathrm{P}(9-(1,96.0 / 2,24)) \leq \leq(9+(1,96.0 /$

2,24))

$\mathrm{P}(9-0 \leq \leq 9+0)$

$\mathrm{P}(9 \leq \leq 9)$

$\mathrm{P}=9$

Firlianty (2009), Ketiadaan jamur dikarenakan bahan baku masih segar dan produk baru saja jadi. Ditambahkan Nani R, (2010), Salah satu faktor yang mempengaruhi pertumbuhan jamur adalah suhu. Suhuakan mempengaruhi reaksi kimiawi dan reaksi enzimatis pada mikroba yang berpengaruh pada pertumbuhan mikroba.Selain itu, suhu juga akan mempengaruhi kecepatan tumbuh pada mikroba.

\section{KESIMPULAN DAN SARAN}

\section{Kesimpulan}

Hasil analisa proksimat :

a. Kadar air 7,2829 \% dan 8,6099 \% telah memenuhi standar nilai persyaratan mutu dan keamanan pangan kerupuk ikan sesuai Standar Nasional Indonesia 
b. Kadar abu tak larut dalam asam 4,4383 $\%$ dan 4,9140 \%, serta kadar protein $3,0000 \%$ dan $3,8629 \%$ tidak memenuhi standar nilai persyaratan mutu dan keamanan pangan kerupuk ikan sesuai Standar Nasional Indonesia

1. Hasil analisa organoleptik :

a. Parameter kenampakan memperoleh nilai $(6,0)$ tidak memenuhi standar nilai persyaratan mutu dan keamanan pangan kerupuk ikan sesuai Standar Nasional Indonesia

b. Parameter bau memperoleh nilai $(7,0)$, rasa (matang) memperoleh nilai $(7,0)$, tekstur memperoleh nilai $(7,0)$, jamur memperoleh nilai $(9,0)$ telah memenuhi standar nilai persyaratan mutu dan keamanan pangan kerupuk ikan sesuai Standar Nasional Indonesia

\section{Saran}

1. Peningkatan higienitas dalam proses pengolahan bahan, pengeringan dan penyimpanan agar mengurangi kadar abu tak larut dalam asam dalam produk

2. Penambahan komposisi daging ikan untuk meningkatkan kadar protein dan proses pengirisan menggunakan alat mekanik sehingga irisan rapi dan seragam

3. Diharapkan melakukan penelitian lebih lanjut dengan komposisi daging ikan yang lebih banyak agar kadar protein dalam produk dapat memenuhi memenuhi standar nilai persyaratan mutu dan keamanan pangan kerupuk ikan sesuai Standar Nasional Indonesia

\section{DAFTAR PUSTAKA}

Adawyah, R. 2007. Pengolahan dan Pengawetan Ikan. Edisi I. Bumi Aksara. Jakarta.

Afrianti M, Dwiloka B, Setiani BE. 2013. Perubahan warna, profil protein, dan mutu organoleptik daging ayam broiler setelah direndam dengan ekstrak daun senduduk. $J$ Apl Teknol Pangan. 2(3): 116-20.

[AOAC] Association of Official Analytical Chemists. 1995. Official Analysis of

The Association of Official Analytical Chemists. Virginia, USA:Published by The Association of Official Analytical Chemists, Inc.Arlington.

Apriliani, M. W. 2010. "Pengaruh Penggunaan Tepung Tapioka dan Carboxymethyl Cellulose (CMC) Pada Pembuatan Keju Mozzarella Terhadap Kualitas Fisik dan Organoleptik" Skripsi Malang: Fakultas Peternakan Universitas Brawijaya.

Apriyantono A. 2002. Pengaruh pengolahan terhadap nilai gizi dan keamanan pangan.http://209.85.175.104/ 
Asrawaty. 2011. Pengaruh suhu dan lama pengeringan terhadap mutu tepung pandan. Jurnal KIAT edisi juni. Universitas Alkhairaat. Palu.

Badan Standardisasi Nasional, Jakarta. Standar Nasional Indonesia 8272:2016

Badan Standardisasi Nasional, Jakarta. Standar Nasional Indonesia2346:2015

Badan Standardisasi Nasional, Jakarta. Standar Nasional Indonesia 2354.1-2010.

Badan Standardisasi Nasional, Jakarta. Standar Nasional Indonesia 2354.2-2015.

Firlianty.2009. Pemanfaatan Limbah Udang (Penaeus sp) sebagai AlternatifBahan Pengolahan Kerupuk untuk Mengurangi ResikoPencemaran Lingkungan. Journal of Tropical Fisheries 4(2): 450-45.

Hapsari, T.P., 2008. Pengaruh pre gelatinisasi pada karakteristik tepung singkong.Primordia 4:91105.

Herliani, L. 2008. Teknologi Pengawetan Pangan. Alfabeta. Bandung.

Huda N., Ang L. L., Chung X. Y. and Herpandi. 2010. Chemical Composition, Colour and Linear Expansion Properties of
Malaysian Commercial Fish Cracker (Keropok). Asian Journal of Food and Agro-Industry 3(05), 473-482 ISSN 1906-3040.

Hui, Yiu H., 2006. Handbook of Food

Science, Technology, and Engineering Volume 1, Taylor \& Francis Group. Boca Raton

Kusnandar,

Ferri. 2011. KimiaPanganKomponen Makro. Dian Rakyat.Jakarta.

Midayanto, D., dan Yuwono, S. 2014. Penentuan atribut mutu tekstur tahu untuk direkomendasikan sebagai syarat tambahan dalam standar nasional indonesia. Jurnal Pangan dan Agroindustri. 2: 4, 259-267

Nani R. Diktat Mikrobiologi Pangan. 2010. Tersedia dari: URL: HYPERLINK http://staff.uny.ac.id/sites/default/f iles/Diktat\%20Bab\%201\%20Mikr obiologi\%20Pangan $\% 20 \% 20$ Prins ip\%20Mikrobiologi\%20Pa\%E2\% $80 \%$ A6.pdf

Nurjanah. 2010. Karakterisasi lintah laut (Discodoris sp.) dari perairan pantaiPulau Buton sebagai antioksidan dan antikolesterol [disertasi]. Bogor:

Sekolah Pascasarjana, Institut Pertanian Bogor. 
SEMAH : Journal Pengelolaan Sumberdaya Perairan

VOL. 2 No. 3

Desember 2018

Purwanto RO, Argo BD, Hermanto MB.

2013. Pengaruh komposisi sirup

glukosa dan variasi suhu pengeringan terhadap sifat fisiko kimia dan inderawi dodol rumput laut (Eucheuma spinosium). $J$ Bioproses Komoditas Tropis.1(1): 1-12. 